\title{
First report of sesame curly top virus infecting vegetables and ornamental plants in Iran
}

\author{
Vahid Hasanvand $^{1} \cdot$ Jahangir Heydarnejad ${ }^{1}$ \\ Received: 2 August 2020 / Accepted: 31 August 2020 / Published online: 7 September 2020 \\ (C) Società Italiana di Patologia Vegetale (S.I.Pa.V.) 2020
}

Keywords Geminiviridae $\cdot$ Turncurtovirus $\cdot$ sesame curly top virus $\cdot$ Kerman province $\cdot$ Iran

Sesame curly top virus (SeCTV) is a new proposed species of the genus Turncurtovirus in the family Geminiviridae and was reported for the first time in sesame in Iran (Hasanvand et al. 2018). To determine the host range of SeCTV, 66 symptomatic plant samples showing yellowing, leaf curling, vein swelling and/or dwarfing were collected between 2017 and 2019 from vegetable and ornamental plants in Kerman province, south-eastern Iran. Total DNA was extracted using the CTAB method as described by Zhang et al. (1998) and subjected to PCR using primer pair LHEcoRV-F: 5'GATATCACTTTGGTAATTGAAGAGAGGGCC-3'/ LHEcoRV-R: 5'-GATATCGAAGCCGAAGAGGAT-3' and Platinum Pfx DNA polymerase (Thermo Fisher Scientific, USA). SeCTV infection was confirmed by PCR in alfalfa (5 of 13 plants), bean ( 5 of 7 plants), eggplant (2 of 6 plants), blanket flower (Gaillardia aristata Pursh, Asteraceae) (3 of 4 plants), faba bean ( 2 of 12 plants), radish ( 6 of 14 plants) and watermelon (10 of 10 plants) samples. The full-length genome of seven SeCTV isolates (one representative for each plant species) was amplified using a combination of rolling circle amplification kit (TempliPhi, GE Healthcare, USA), as described by Haible et al. (2006), and PCR. PCR amplicons with the expected size of $\sim 3 \mathrm{~kb}$ were resolved by electrophoresis on $0.7 \%$ agarose gels, cloned and sequenced (GenBank accession numbers MT041691-MT041697). The full-length genome of all ScCTV isolates from the seven natural hosts was $2972 \mathrm{nts}$ in size and shared 96.9-99.3\% nucleotide identity among themselves and $97.7-99.7 \%$ with a sesame isolate (MH595443). This finding indicated that SeCTV is widespread in vegetables crops in Kerman province of Iran. To the best of our knowledge, this is the first report of SeCTV infecting faba bean, radish, alfalfa, bean, eggplant, watermelon and blanket flower.

Funding This research work was supported by Research and Technology Institute of Plant Production (RTIPP), Shahid Bahonar University of Kerman (Project No. 97-1-1).

\section{Compliance with ethical standards}

Conflict of interest The authors declare that they have no conflict of interest.

Ethical approval This article does not contain any studies with human participants or animals performed by any of the authors.

\section{References}

Haible D, Kober S, Jeske H (2006) Rolling circle amplification revolutionizes diagnosis and genomics of geminiviruses. J Virol Methods 135:9-16. https://doi.org/10.1016/j.jviromet.2006.01.017

Hasanvand V, Kamali M, Heydarnejad J, Massumi H, Kvarnheden A, Varsani A (2018) Identification of a new turncurtovirus in the leafhopper Circulifer haematoceps and the host plant species Sesamum indicum. Virus Genes 54:840-845. https://doi.org/10.1007/s11262018-1604-x

Zhang YP, Uyemoto JK, Kirkpatrick BC (1998) A small-scale procedure for extracting nucleic acids from woody plants infected with various phytopathogens for PCR assay. J Virol Methods 71:45-50. https:// doi.org/10.1016/S0166-0934(97)00190-0
Jahangir Heydarnejad

jheydarnejad@uk.ac.ir

1 Shahid Bahonar University of Kerman, Kerman 7616914111, Iran 